\title{
The insecticidal potential of Foeniculum vulgare Mill., Pimpinella anisum L. and Caryophillus aromaticus L. to control aphid on kale plants
}

LUCCA, P.S.R.'; NÓBREGA, L.H.P.'; ALVES, L.F.A.;; CRUZ-SILVA C.T.A. ${ }^{*}$; PACHECO, F.P. ${ }^{2}$

${ }^{1}$ Faculdade Assis Gurgacz - FAG, Curso de Farmácia. Avenida das Torres, 500. Bairro FAG. CEP 85814-620. Cascavel - Paraná. ${ }^{2}$ Universidade Estadual do Oeste do Paraná, Campus de Cascavel, Centro de Ciências Exatas e Tecnológicas. Rua Universitária, 2069. Jardim Universitário. CEP 85819-110. Cascavel - Paraná. ${ }^{3}$ Universidade Estadual do Oeste do Paraná, Campus de Cascavel, Centro de Ciências Biológicas e da Saúde, Laboratório de Zoologia. Rua Universitária, 2069. Jardim Universitário. CEP 85819-110. Cascavel - Paraná. *Autor para correspondência: claudia_petsmart@hotmail.com.

\begin{abstract}
The use of natural substances for pest control in agriculture is, economically, a viable option and has benefits for both the humanbeing and the environment, due to its low persistence and toxicity. Thus, this trial aimed on determining the insecticidal potential of the extracts and essential oils of fennel (Foeniculum vulgare Mill.), anise (Pimpinella anisum L.) and clove (Caryophillus aromaticus L.) to control Brevicoryne brassicae L. in kale (Brassica oleracea var. acephala DC.). The treatments were: fennel, anise, cloves extracts at $10 \%$; fennel, anise, cloves oils at $1 \%$ and control with distilled water. The mortality tests were carried out with aphids in laboratory, with three replications, after 1, 12, 24, 48 and 72 hours. During laboratory trials, it was found out that fennel oil at $1 \%$ showed the best rate of mortality on aphid nymphs $(70 \%$ at $72 \mathrm{~h}$ ), followed by clove extract at $10 \%$ with $37 \%$ mortality. Tests in pots were only carried out only with cloves extracts at $10 \%$ and fennel oil at $1 \%$ treatment, in which such efficiency was alsoindicated on aphid nymphs.
\end{abstract}

Keywords: botanic insecticides, repellency, essential oils.

RESUMO: Potencial inseticida de Foeniculum vulgare Mill., Pimpinella anisum L. e Caryophillus aromaticus L. no controle de pulgão em couve. O uso de produtos naturais para controle de pragas da agricultura é opção economicamente viável e traz benefícios tanto ao homem como ao ambiente devido à sua baixa persistência e toxicidade. Dessa forma, o objetivo deste trabalho foi verificar o potencial inseticida de extratos e óleos essenciais de funcho (Foeniculum vulgare Mill.), erva doce (Pimpinella anisum L.) e cravo-da-índia (Caryophillus aromaticus L.) para o controle de pulgão (Brevicoryne brassicae L.) em couve (Brassica oleracea var. acephala DC.). Os tratamentos utilizados foram os extratos de funcho, erva-doce e cravoda-índia a 10\%; óleos de funcho, erva-doce, cravo-da- índia a $1 \%$ e testemunha com água destilada. Testes de mortalidade sobre pulgão em condições de laboratório foram realizados com três repetições e avaliações após 1, 12, 24, 48 e 72 h. Em laboratório, verificou-se que o óleo de funcho a $1 \%$ apresentou maior atividade sobre as ninfas de pulgão (70\% em $72 \mathrm{~h}$ ), seguido do extrato de cravo a $10 \%$, com $37 \%$ de mortalidade. Testes em vasos foram realizados somente com o extrato de cravo-da-índia a $10 \%$ e óleo de funcho a $1 \%$, nos quais também se constatou a eficácia sobre as ninfas de pulgão.

Palavras-chave: inseticidas botânicos, repelência, óleos essenciais.

\section{INTRODUCTION}

Kale (Brassica oleracea var. Acephala DC.) has been considered one of the most important oleraceous plant for human feeding, since it is rich in calcium, iron, vitamin A, niacin and ascorbic acid (Franco, 1960). Among several pests which affect
Kale, there are some caterpillars as: Ascia monuste orseis (Latr.), Plutella xylostella L., Agrotis ipsilon (Hufnagel), Trichoplusia ni (Hueb) and aphids, but especially Brevicoryne brassicae L. can be highlighted from those ones (Gallo et al., 2002). 
In Brazil, $B$. brassicae is considered a very important pest due to growing demand to obtain products with high quality and the difficulties to control effectively such insect in several crops (Longhini \& Busoli, 1993).

Oleraceous farmers should take specific managements to control infestations by pests; however, chemical insecticides have still been the most usual method for such control. These applications also cause some disadvantages such as environmental pollution, and human poisoning (Picanço et al., 2005).

Some plants, throughout their evolution, have developed their own chemical defense against herbivores, since they synthesize secondary metabolites with insecticidal properties, i.e., with toxic activity against insects or cause their death by other actions, or even repellency.

The botanic insecticides come from these plants or their parts. They are ground to be powdered or diluted in aqueous extraction, or organic solvents such as alcohol, ether, acetone, chloroform, etc. or distillation (Wiesbrook, 2004).

According to Côrrea \& Salgado (2011), there are several plants that have insecticidal activity and should be studied and introduced, when possible, on farms as an alternative form of pest control, as well as a potential tool to manage them.

Extracts and oils produced by plants have been investigated as potential insect repellents. So, some results are observed with oil applications, from maize weevil adults (Sitophilus zeamais Mots) such as: Eucalyptus globulus Labill, Eucalyptus citriodora Hook, Azadirachta indica A. Juss, Lippia gracillis HBK, Cedrela fissilis Vell, Caryocar brasiliense Camb and Caropa guianensis Aubl (Coitinho et al., 2006).

Also, oils of Illicium verum L. fruits and Cymbopogon citratus Stapf $\mathrm{L}$. leaves were used on B. brassicae (Lima et al., 2008); ethanolic extract of green and ripe Melia azedarach L. fruits on Aedes aegypti L. (Prophiro et al., 2008); ethanol extract of Ipomoea carnea subsp fistulosa and Ricinus communis L., aqueous extract of Mascagnia rigida Griseb and Argemone mexicana L. and Azadirachta indica A. Juss oil to control Bemisia tabaci biotype B (Lima et al., 2011).

In this context, the use of botanic insecticides comes as an alternative to control pests. They are considered an important group of natural occurring, often slow-acting crop protectants that are usually safer to humans and the environment than conventional pesticides, with minimal residual effects. Therefore, the use of plant pesticides has been recommended ever more as a suitable alternative of plant protection with minimum negative risks (Pavela, 2009).

They offer new action ways that may provide effective pest control that have already developed resistance to conventional insecticides. They also offer cost-effective pest control to smallholder farmers in developing countries if highly active extracts can be prepared simply from readily available plants (Amoabeng et al., 2013).

Thus, this study aimed at investigating the insecticidal potential of extracts and essential oils of fennel, anise and clove to control B. brassicae in kale under both laboratory and field conditions.

\section{MATERIAL AND METHODS}

The test plants, dried at $40{ }^{\circ} \mathrm{C}$, were obtained from Santosflora Ervas, Especiarias e Extratos Secos Company, in São Paulo city, in order to prepare plants extracts. During this research, Foeniculum vulgare Mill. (Umbelliferae) fruits, Pimpinella anisum L., (Umbelliferae) fruits and Caryophillus aromaticus L. (Myrtaceae) flower buds were used.

Test plants were used to obtain the studied extracts and submitted testing technique hydroalcoholic extraction (Farmacopéia Brasileira, 1988). Essential oils of plants were also obtained by steam distillation in Clevenger equipment as recommended by the Brazilian Pharmacopeoeia (1988).

Insecticidal effects of extracts and essential oils on Brevicoryne brassiceae nymphs: solutions were prepared at $1 \%$ concentration of based on essential oils of clove, fennel, anise, as well as solutions at $10 \%$ extract of cloves, fennel and anise, all added with $0.1 \%$ Tween.

The aphids used on bioassays were collected from natural infestations in kale ( $B$. oleracea var. acephala), field cropped, which composed a breeding storage, at Assis Gurgacz College, Farm School, in Cascavel city, Paraná.

The studied insects were selected by size $(1.5 \mathrm{~mm})$ as well as the control treatment (only distilled water), under laboratory conditions. Three replications for each treatment were prepared and each kale leaf was considered as a replication (10 to $15 \mathrm{~cm}$ diameter). It was put in a Petri dish with moister cotton under each leaf and around the petiole. Ten aphid nymphs were released in each plate and then $1 \mathrm{~mL}$ of the product was sprayed with the respective solutions, according to the modified methodology from Vasconcelos et al. (2006). Then, the plates were covered with plastic film perforated with pins and taken to the incubation chamber during a 12 hour photoperiod at $25^{\circ} \mathrm{C}$.

The evaluations were carried out after 1,12 , 24,48 and 72 hours, removing dead insects, when they did not answer to any stimulus. 
Insecticidal effects of extracts and essential oils on Brevicoryne brassiceae adult insects: The same procedure described above was performed with $2.5 \mathrm{~mm}$ aphids. The evaluations were performed after 1, 12, 24, 48 and 72 hours in which the number of dead insects was counted.

Cropping test: kale seeds (Isla brand) were sown in polystyrene trays with Plantmax ${ }^{\circledR} \mathrm{HA}$ vegetables substrate in a greenhouse. After 30 days, they were transplanted to $500 \mathrm{~mL}$ plastic pots containing soil and organic fertilizer in a 2:1 ratio. Five replications (pots) were cropped by treatment and each pot contained one plant.

The tests were performed with treatments that had the best results in laboratory tests $(10 \%$ clove extract, $1 \%$ fennel oil and control).

The pots were placed in a greenhouse, and watered four times a week. After the plants have gotten rooted, almost in 30 days, ten aphids with $1.5 \mathrm{~mm}$ long were transferred to each pot and distributed on kale leaves. The next step was to apply the studied solutions in plants with a hand sprayer. Almost $1 \mathrm{~mL}$ of each solution was sprayed on a kale leaf. The pots were wrapped with thin tissue "voile", tied with twine. The evaluations were carried out after 1, 12, 24, 48 and 72 hours.

Statistics: A completely randomized design was used with seven treatments and three replications for the experiments on Brevicoryne brassiceae nymphs and adult insects. For the Cropping test, three treatments and five replications were used. All results were submitted to analysis of variance and the averages were compared by Tukey test at $5 \%$ probability, with Minitab 14 software.

The average percentage of $B$. brassicae nymphs and adult insects' mortality in the studied treatments and the evaluation periods were transformed by $\sqrt{(x+0,5) / 100}$, corrected by Schneider - Orelli (1947) method.

Regression curves were obtained by Microsoft Excel software.

\section{RESULTS AND DISCUSSION}

Identity and quality evaluation of fennel, cloves and anise samples confirmed their own identity as well as quality criteria, indicating that all of them are in accordance with the parameters established by the Brazilian Pharmacopoeia IV (Table 1).

It was found out that the treatments showed a statistic significant difference after 24 hour nymphs' exposure, regarding the insecticidal effect of the extracts and essential oils on $B$. brassiceae nymphs (Table 2).

Fennel oil $1 \%$ caused greater nymph mortality ( $70 \%$ in 72 hours) and differed significantly from all tested treatments. The control treatment showed the lowest mortality percentages. Although they have shown no statistic significant differences on $10 \%$ fennel extract, $1 \%$ anise and clove oils after 72 hours (Table 2 ).

Fennel, anise and clove extracts at $10 \%$, anise oil at $1 \%$, plus the control did not increase nymph mortality after 24 hours of exposure, but $1 \%$ clove oil stabilized after 48 hours.

Anise and clove extracts at $10 \%$ and clove oil at $1 \%$ caused intermediate mortality. Although it may be noted that at 72 hours, $1 \%$ fennel oil showed greater mortality, thus, it was statistically significant in relation to the others.

In this context, Ebadollahi (2013a) reported that essential oils from plants may be an alternative source of insect control agents, since they constitute a rich source of bioactive compounds that are biodegradable into nontoxic products and potentially suitable to be used in integrated management programs.

When the corrected aphid mortality is analyzed according to Schneider Orelli (1947) method and the regression curve, it is observed again the superiority of fennel oil treatment at $1 \%$ with corrected mortality of $66.7 \%$.

The best equation selection was taken according to the coefficient of determination $\left(R^{2}\right)$

TABLE 1. Identity and quality evaluations of plant samples used to manufacture extracts and essential oils extraction.

\begin{tabular}{lccc}
\hline Test plant & Water content & Total ashes & Essential oil content \\
& $\%$ & 8.6 & $\%$ \\
\hline Foeniculum vulgare Muller - dry fruits & 7.9 & 5.8 & 1.7 \\
Caryophillus aromaticus L. - flower botton & 6.8 & 6.0 & 2.1 \\
Pimpinella anisum L.- dry fruits & 5.8 & 2.0 \\
\hline
\end{tabular}

Note: Sensorial features and macroscopic and microscopic identification according to Brazilian Pharmacopoeia IV. 
TABLE 2. Cumulative mortality percentage of Brevicoryne brassicae nymphs submitted to treatments with biological insecticides and evaluation periods.

\begin{tabular}{|c|c|c|c|c|c|c|}
\hline \multirow[t]{2}{*}{ insecticides } & \multicolumn{5}{|c|}{ Hours } & \multirow{2}{*}{$\begin{array}{c}\text { Corrected } \\
\text { average } \\
\text { mortality (\%) }\end{array}$} \\
\hline & 1 & 12 & 24 & 48 & 72 & \\
\hline Control & $0 \mathrm{a}$ & $0 \mathrm{a}$ & $10 \mathrm{~b}$ & $10 \mathrm{~b}$ & $10 \mathrm{~b}$ & - \\
\hline $10 \%$ fennel extract & $0 \mathrm{a}$ & $13 a$ & $17 \mathrm{bc}$ & $17 \mathrm{bc}$ & $17 \mathrm{bc}$ & 7.8 \\
\hline $10 \%$ anise extract & $3 a$ & $10 a$ & $27 \mathrm{~cd}$ & $27 \mathrm{~cd}$ & $27 \mathrm{bc}$ & 18.9 \\
\hline $10 \%$ clove extract & $13 a$ & $23 a$ & $37 d$ & $37 d$ & $37 \mathrm{~cd}$ & 30.0 \\
\hline $1 \%$ fennel oil & $0 \mathrm{a}$ & $10 \mathrm{a}$ & $20 \mathrm{bc}$ & $33 \mathrm{~cd}$ & $70 \mathrm{e}$ & 66.7 \\
\hline $1 \%$ anise oil & $0 \mathrm{a}$ & $3 a$ & $17 \mathrm{bc}$ & $17 \mathrm{bc}$ & $17 \mathrm{bc}$ & 7.8 \\
\hline $1 \%$ clove oil & $0 \mathrm{a}$ & $3 a$ & $10 \mathrm{~b}$ & $20 \mathrm{bc}$ & $20 \mathrm{bcd}$ & 11.1 \\
\hline
\end{tabular}

Averages followed by the same letter in the column do not differ by themselves according to Tukey test at $5 \%$ probability. The data presented are from the original averages. For statistical analysis, the data were transformed into. $\sqrt{(x+0,5) / 100}$

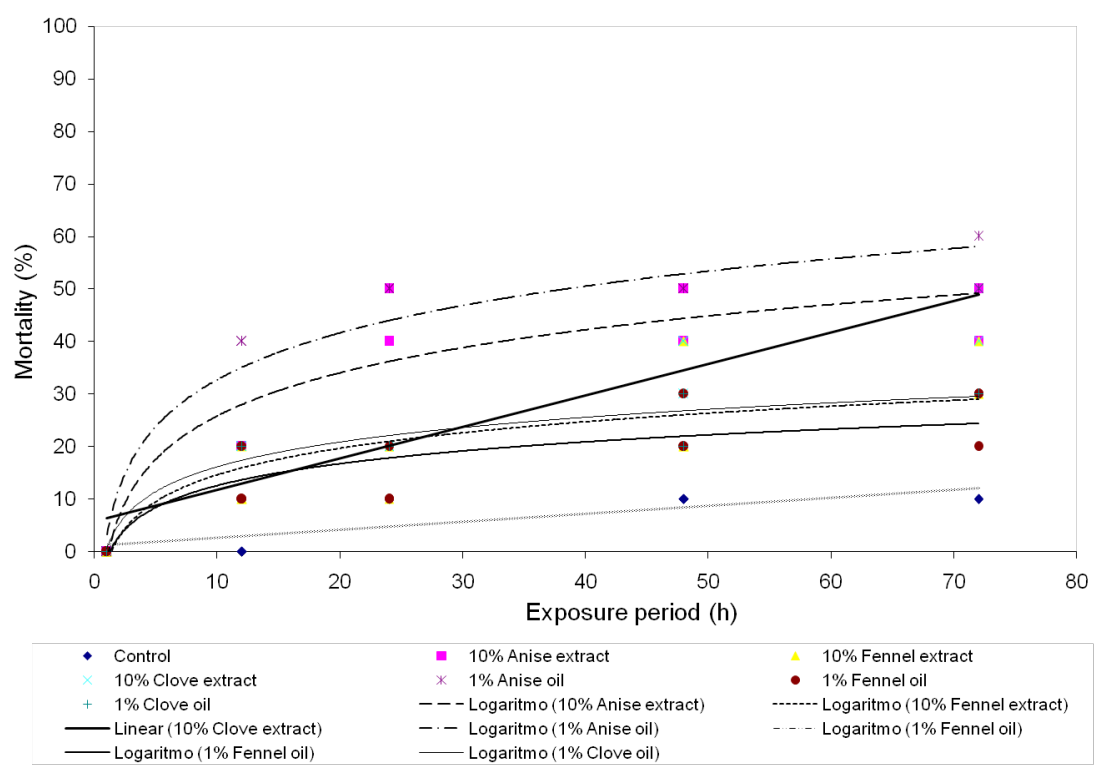

FIGURE 1. Curves of mortality percentage versus period $(h)$ for insecticidal effect of botanic extracts against Brevicoryne brassicae nymphs.

(Figure 1 and Table 3). In regression analysis, it was observed that the $1 \%$ fennel and clove oils showed the best results with linear regression, whose $\mathrm{R}^{2}$ values were 0.91 and 0.62 , respectively.

Once, it was observed the superiority of $1 \%$ fennel oil treatment with $47.8 \%$ corrected mortality. Followed by $10 \%$ fennel and clove extracts, both with $41.1 \%$ mortality on $B$. brassicae adult insects (Table 4).

According to Ebadollahi (2013b), the Umbelliferae family has been known as excellent sources of essential oil with insecticidal properties. According to Alves (2001), the essential oils obtained from plants are considered great sources of active biological substances. Similar to what was observed in this study, several trials that have been carried out with fennel oil showed insecticidal activity. Digilio et al., (2008) recorded some activity of fennel essential oil steam at $2 \mu \mathrm{l}$ $\mathrm{L}^{-1}$ concentration on Acyrthosiphon pisum Harris and Myzus persicae Sulzer aphids. Aroiee et al. (2005) observed insecticidal activity of fennel oil at 
TABLE 3. Regression equations among nymph mortality percentage and exposure period to the studied extracts and oils with insecticidal potential.

\begin{tabular}{ccc}
\hline Treatments & Equations & $\mathrm{R}^{2}$ \\
\hline Control & $\mathrm{y}=2.6642 \operatorname{Ln}(\mathrm{x})-1.3657$ & 0.68 \\
$10 \%$ fennel extract & $\mathrm{y}=4.1182 \operatorname{Ln}(\mathrm{x})+1.2915$ & 0.65 \\
$10 \%$ anise extract & $\mathrm{y}=6.0573 \operatorname{Ln}(\mathrm{x})+1.9355$ & 0.53 \\
$10 \%$ clove extract & $\mathrm{y}=5.9738 \operatorname{Ln}(\mathrm{x})+12.819$ & 0.31 \\
$1 \%$ fennel oil & $\mathrm{y}=0.9311 \mathrm{x}-2.5705$ & 0.91 \\
$1 \%$ anise oil & $\mathrm{y}=4.36 \operatorname{Ln}(\mathrm{x})-1.3801$ & 0.59 \\
$1 \%$ clove oil & $\mathrm{y}=0.3066 \mathrm{x}+1.0401$ & 0.62 \\
\hline
\end{tabular}

TABLE 4. Cumulative mortality percentage of Brevicoryne brassicae adults and corrected mortality submitted to treatments with biological insecticides and exposure period.

\begin{tabular}{|c|c|c|c|c|c|c|}
\hline \multirow{2}{*}{ Period plus botanical } & \multicolumn{5}{|c|}{ Hours } & \multirow{2}{*}{$\begin{array}{c}\text { Corrected } \\
\text { average } \\
\text { mortality }(\%)\end{array}$} \\
\hline & 1 & 12 & 24 & 48 & 72 & \\
\hline Control & $0 \mathrm{a}$ & $0 \mathrm{a}$ & $10 a b$ & $10 a$ & $10 a$ & - \\
\hline $10 \%$ fennel extract & $0 \mathrm{a}$ & $20 \mathrm{~b}$ & $43 c$ & $47 \mathrm{c}$ & $47 \mathrm{c}$ & 41,1 \\
\hline $10 \%$ anise extract & $0 \mathrm{a}$ & $13 b$ & $17 a b$ & $27 \mathrm{~b}$ & $43 \mathrm{~b}$ & 25,5 \\
\hline $10 \%$ clove extract & $0 \mathrm{a}$ & $20 \mathrm{~b}$ & $20 \mathrm{~b}$ & $37 \mathrm{bc}$ & $37 c$ & 41,1 \\
\hline $1 \%$ fennel oil & $0 \mathrm{a}$ & $40 \mathrm{c}$ & $50 \mathrm{c}$ & $50 \mathrm{c}$ & $53 \mathrm{c}$ & 47,8 \\
\hline $1 \%$ anise oil & $0 \mathrm{a}$ & $13 b$ & $13 a b$ & $23 a b$ & $27 \mathrm{~b}$ & 18,9 \\
\hline $1 \%$ clove oil & $0 \mathrm{a}$ & $20 \mathrm{~b}$ & $20 \mathrm{~b}$ & $27 \mathrm{~b}$ & $30 \mathrm{~b}$ & 22,2 \\
\hline
\end{tabular}

Averages followed by the same letter in the column do not differ by themselves according to Tukey test at $5 \%$ probability.

5 ppm concentration for Trialeurodes vaporariorum Westwood.

Thus, as observed in this study, the insecticide and repellent activity of clove has also been reported. Inyang \& Emosairue (2005) registered repellent activity of clove aqueous extracts on Cosmopolites sordidus Germ. and assumed such effect as a pungent characteristic, which suggests that it has a fumigant action on insects. According to Ho et al. (1994), rice grains treated with hexanic and methanolic extracts of clove at $1 \mathrm{~mL}$ for each $100 \mathrm{~g}$ rice reduced significantly Sitophilus zeamais adults' emergence.

Anise insecticidal activity was also related by Tunç \& Sahinkaya (1998) that verified some anise acaricide activity on Tetranychus cinnabarinus Boisd. On fumigation tests, Mairesse (2005) observed an important potential insecticide characteristic of anise since it showed a repellent activity moth. Anetol phenylpropanoid, the most important component of anise, was very efficient to control Aedes aegypti and Culex pipiens L. (Knio et al., 2007).

Thus, this study has shown results that indicate low activity of anise treatment on Brevicoryne brassicae. Such fact could be due to the real inefficiency of treatments or to some chemical changes concerning the use of anise. According to Robbers (1997), more than 200 constituents can be found in plants volatile oils of the same species when grown in different parts of the world. Essential oils can provide, a rule, with the same qualitative composition, yet, differing proportions of their constituents, which can result in differences in performance and/or insecticidal effect.

Kale crop tests were carried out only with the extract and oil which showed the highest percentage of nymphs' mortality. Thus, the treatments effectiveness was verified on aphids mortality, wherein the $10 \%$ clove extract and $1 \%$ fennel oil reached the corrected mortality (94 and 92\%, respectively) (Table 5). They differed from the control after 24 hours of exposure to treatments, although $10 \%$ clove extract was more 
TABLE 5. Cumulative mortality percentage of aphids and corrected mortality submitted to $1 \%$ fennel oil and $10 \%$ clove extract treatments on Brevicoryne brassicae adult insects in Brassica oleracea crop.

\begin{tabular}{|c|c|c|c|c|c|}
\hline \multirow{2}{*}{$\begin{array}{l}\text { Period plus botanical } \\
\text { insecticides } \\
\text { Treatment }\end{array}$} & \multicolumn{4}{|c|}{ Hours } & \multirow{2}{*}{$\begin{array}{l}\text { Corrected } \\
\text { mortality \% }\end{array}$} \\
\hline & 12 & 24 & 48 & 72 & \\
\hline Control & $0 \mathrm{a}$ & $0 \mathrm{a}$ & $0 \mathrm{a}$ & $0 \mathrm{a}$ & - \\
\hline $10 \%$ clove extract & $16 \mathrm{~b}$ & $52 \mathrm{c}$ & $74 \mathrm{c}$ & $94 \mathrm{~b}$ & 94 \\
\hline $1 \%$ fennel oil & $4 \mathrm{a}$ & $34 \mathrm{~b}$ & $58 \mathrm{~b}$ & $92 \mathrm{~b}$ & 92 \\
\hline
\end{tabular}

Averages followed by the same letter in the column do not differ by themselves according to Tukey test at $5 \%$ probability.

effective in 24 and 48 hour exposure period. The fennel oil reached an equivalent activity to the clove extract in 72 hours.

Castelo Branco et al. (2003) tested a commercial insecticide and assumed that an effective insecticide should cause more than $90 \%$ larval mortality. In this study, the clove extract and fennel oil caused more than $90 \%$ adult insects mortality.

During crop test, after treatments application and sunlight incidence, there was some phototoxicity of $1 \%$ fennel oil when sprayed on kale leaves. This phototoxicity may have occurred by the furanocoumarins oil presence.

According to Simões et al. (2007), the Umbeliferae family, which fennel belongs, usually presents furanocoumarins in its composition. These substances strongly absorb energy in the UV region and are therefore strongly reactive under light incidence and when photo-activated, bind themselves to DNA pyrimidine bases and cause cytoplasmic mutations.

The $1 \%$ fennel oil and $10 \%$ clove extract treatments showed the greatest activity on aphids' mortality. This effectiveness may be due to terpenoids and/or phenylpropanoids presence. Since, both fennel and clove are plants rich in essential oils composed mainly by phenylpropanoids and terpenoids.

The most important fennel oil components are anethole, fenchone, myristicin and estragole. Anethole is a phenylpropanoid and the other components are terpenoids. Clove is rich in essential oil, which contains 70 to $95 \%$ phenylpropanoid called eugenol, and 5 to $8 \%$ beta-caryophyllene (Simões et al., 2007).

Several terpenoids have insecticidal properties, such as azadirachtin from neem; terpenes from pine; nerol from lemongrass, menthol from mint (Carvalho et al., 2008.).

Fennel insecticidal activity can be associated to its composition. So, according to Lee et al. (2003), the fumigant effect of fenchone, a terpenoid that is present in fennel, caused $100 \%$ mortality on five species of insects (Sytophilus oryzae, Tribolium castaneum, Oryzaephilus surinamensis, Musca domestica e Blattella germanica).

Kim \& Ahn (2001) also evaluated the insecticidal effect of fennel constituents: fenchone, anethole and estragole. They also found out some insecticidal potential of three components on the rice weevil (Sitophilus oryzae), bean weevil (Callosobruchus chinensis) and weevil-tobacco (Lasioderma serricorne).

Simple terpenoids, such as the fennel terpenoids, showed insecticidal action with acetylcholinesterase inhibition in insects, as reported by Viegas Junior (2003).

There are also some reports of insecticidal activity for phenylpropanoids. According to Coitinho et al. (2006), the eugenol, a phenylpropanoid present in clove, was effective in controlling weevil adults on corn (S. zeamais) during the initial stage of storage. Simas (2004) demonstrated that eugenol has larvicidal activity against the third instar larvae of Aedes aegypti.

Under the conditions of this study, it can be concluded that $10 \%$ clove extract and $1 \%$ fennel oil showed insecticidal potential against nymphs and adult insects of Brevicoryne brassicae on kale plants. However, $1 \%$ fennel oil showed phototoxic activity against kale leaves.

\section{ACKNOWLEDGEMENT}

The authors thank Assis Gurgacz College for its support and for the granted scholarship to the first author during this trial.

\section{REFERENCES}

ALVES, H. M. A diversidade química das plantas como fonte de fitofármacos. Cadernos temáticos de química nova na escola, n.3, p.10-15, 2001.

AMOABENG, B.W. et al. Tri-trophic insecticidal effects of African plants against cabbage pests. Plos One, v.8, n.10, p.1-10, 2013. 
AROIEE, H. et al. Effect of essencial oils of fennel. caraway and rosemary on greenhouse whitefly (Trialeurodes vaporariorum). KMITL Science and Technology Journal, v.5, n.2, p.6-11, 2005.

CARVALHO, G. A. et al. Eficiência do óleo de nim (Azadirachta indica a. Juss) no controle de Brevicoryne brassicae (Linnaeus, 1758) e Myzus persicae (Sulzer, 1776) (Hemiptera: Aphididae) em couve-manteiga Brassica oleracea Linnaeus var. acephala. Arquivos do Instituto Biológico, v.75, n.2, p.181-186, 2008.

CASTELO BRANCO, M. et al. Avaliação da suscetibilidade a inseticidas de populações da traça-das-crucíferas de algumas áreas do Brasil. Horticultura Brasileira, v.21, n.3, p.549-552, 2003.

COITINHO, R.L.B.C. et al. Atividade inseticida de óleos vegetais sobre Sitophilus zeamais MOTS. (Coleoptera: Curculionidae) em milho armazenado. Caatinga, v.19, n.2, p.176-182, 2006.

CÔRREA, J.C.R.; SALGADO, H.R.N. Atividade inseticida das plantas e aplicações: revisão. Revista Brasileira de Plantas Medicinais, v.13, n.4, p.500-506, 2011.

DIGILIO, M.C. et al. Insecticide activity of Mediterranean essential oils. Journal of Plant Interactions, v.3, n.1, p.17-23, 2008.

EBADOLLAHI, A. Essential oils isolated from Myrtaceae family as natural insecticides. Annual Review \& Research in Biology, v.3, n.3, p.148-175, 2013a.

EBADOLLAHI, A. Plant essential oils from Apiaceae family as alternatives to conventional insecticides. Ecologia Balkanica, v.5, n.1, p. 149-172, 2013b.

FARMACOPÉIA BRASILEIRA. 4. ed. São Paulo: Atheneu, 1988. 112p.

FARMACOPÉIA HOMEOPÁTICABRASILEIRA. 2.ed. São Paulo: Atheneu, 1997. 349p.

FRANCO, G. Tabela de composição química de alimentos. 3.ed., Rio de Janeiro: Serviço de Alimentação da Previdência Social, 1960. 194p.

GALLO, D. et al. Entomologia agrícola. Piracicaba: FEALQ., 2002. 920p.

HO, S.H. et al. Potential of cloves (Syzygium aromaticum (L.) Merr. and Perry as a grain protectant against Tribolium castaneum (Herbst) and Sitophilus zeamais Motsch. Postharvest Biology Technology, v.33, n.2, p.179-183, 1994.

INYANG, U.E.; EMOSAIRUE, S.O. Laboratory assessment of the repellent and anti-feedant properties of aqueous extracts of 13 plants against the banana weevil Cosmopolites sordidus Germar (Coleoptera: Curculionidae). Tropical and Subtropical Agroecosystems, v.5, n.3, p.33-44, 2005.

KIM, D.; AHN, Y. Contact and fumigant activities of constituent of Foeniculum vulgare fruit against three coleopteran stored product insects. Pest Management Science, v.57, n.3, p.301-306, 2001.

$\mathrm{KNIO}$, K.M. et al. Larvicidal activity of essential oils extracted from commonly used herbs in Lebanon against the seaside mosquito, Ochlerotatus caspius. Bioresource Technology, v.99, n.4, p.763-768, 2007.

LEE, S. et al. Fumigation toxicity of monoterpenoids to several stored product insect. Journal of Stores
Products Research, v.39, n.1, p.77-85, 2003.

LIMA, R. K. et al. Composição dos Óleos Essenciais de Anis-estrelado Illicium verum L. e de Capim-limão Cymbopogon citratus (DC.) Stapf: Avaliação do Efeito Repelente sobre Brevicoryne brassicae (L.) (Hemiptera: Aphididae). BioAssay, v.3, n.8, p.1-6, 2008.

LIMA, B.M.F.V. et al. Avaliação de extratos vegetais no controle de mosca branca em tomate. Revista Caatinga, v. 24, n. 4, p. 36-42, 2011.

LONGHINI, L.C.S.B.; BUSOLI, A.C. Controle integrado de Brevicoryne brassicae (L.. 1758) (Homoptera: Aphididae) e Ascia monuste orseis (Latr.. 1819) (Lepidoptera: Pieridae) em couve (Brassica oleraceae var. acephala). Científica, v.21, n.2, p.231-237, 1993.

MAIRESSE, L.A.S. Avaliação da bioatividade de extratos de espécies vegetais enquanto excipientes de aleloquímicos. 2005. 326p. Tese (Doutorado em Agronomia). Universidade Federal de Santa Maria, Santa Maria.

PAVELA, R. Effectiveness of Some Botanical Insecticides against Spodoptera littoralis Boisduvala (Lepidoptera: Noctudiae), Myzus persicae Sulzer (Hemiptera: Aphididae) and Tetranychus urticae Koch (Acari: Tetranychidae). Plant Protection Science, v.45, n.4, p. 161-167, 2009.

PICANÇO, M. C. et al. Manejo integrado de pragas de hortaliças. In: Fontes. P.C.R. Olericultura: teoria e prática. Viçosa: UFV, 2005. p.159-168.

PROPHIRO, J.S. et al. Estudo comparativo do efeito larvicida de extratos de frutos verdes e maduros de Melia azedarach L. (Sapindales: Meliaceae) em Aedes aegypti L. (Diptera: Culicidae). BioAssay, v.3, n.8, p.1-5, 2008.

ROBBERS, J. E. Farmacognosia e famacobiotecnologia. São Paulo: Editora Premier, 1997. 372p.

SCHNEIDER-ORELLI, O. Entomoligisches praktikum. Aarau: Sauerlander, 1947. 149p.

SIMAS, N.K. et al. Produtos naturais para o controle da transmissão da dengue : atividade larvicida de Myroxylon balsamum (óleo vermelho) e de terpenóides e fenilpropanóides. Química Nova, v.27, n.1, pp. 4649, 2004.

SIMÕES C.M.O. et al. Farmacognosia: da planta ao medicamento. 6. ed., Rio Grande do Sul: Ed. UFSC e URFGS, 2007. 1102p.

TUNÇ, I.; ŞAHINKAYA, S. Sensitivity of two greenhouse pests to vapours of essential oils. Entomologia Experimentalis et Applicata, v.86, n.2, p.183-187, 1998.

VASCONCELOS, G.J.N. et al. Extratos aquosos de Leucaena leucocephala e Sterculia foetidia no controle de Bemisia tabaci biótipo B (Hemiptera: Aleyrodidae). Ciência Rural, v.36, n.5, p.1353-1359, 2006.

VIEGAS JUNIOR, C. Terpenos com atividade inseticida: uma alternativa para o controle químico de insetos. Química Nova, v.26, n.3, p.390-400, 2003.

WIESBROOK, M. L. Natural indeed: Are natural insecticides safer and better than conventional insecticides? Illinois Pesticide Review, v.17, n.3, p.333-370, 2004. 